of social and communication deficits associated with the spectrum of autism. J Autism Dev Disord 2000; 30: 205-23.

33 Wechsler D. The Wechsler Abbreviated Scale of Intelligence - UK. The Psychological Corporation, 1999.

34 Macintyre S, Ellaway A, Der G, Ford G, Hunt K. Do housing tenure and car access predict health because they are simply markers of income or self esteem? A Scottish study. J Epidemiol Community Health 1998; 52: 657-64.

35 National-Statistics. Measuring deprivation in England and Wales using 2001 Carstairs scores. Health Stat Q 2006; 31: 28-33.

36 Frick PJ, Hare RD. Antisocial Process Screening Device: APSD. Multi-Health Systems, 2001.

37 McMahon RJ, Witkiewitz K, Kotler JS. Predictive validity of callousunemotional traits measured in early adolescence with respect to multiple antisocial outcomes. J Abnorm Psychol 2010; 119: 752.

38 Dadds MR, Fraser J, Frost A, Hawes DJ. Disentangling the underlying dimensions of psychopathy and conduct problems in childhood: a community study. J Consult Clin Psychol 2005; 73: 400.

39 Goodman R, Ford T, Simmons H, Gatward R, Meltzer H. Using the Strengths and Difficulties Questionnaire (SDQ) to screen for child psychiatric disorders in a community sample. Br J Psychiatry 2000; 177: 534-9.

40 Constantino JN, Davis SA, Todd RD, Schindler MK, Gross MM, Brophy SL, et al. Validation of a brief quantitative measure of autistic traits: comparison of the social responsiveness scale with the autism diagnostic interview-revised. J Autism Dev Disord 2003; 33: 427-33.

41 Ekman P, Friesen WV, Press CP. Pictures of Facial Affect. Consulting Psychologists Press, 1975.

42 Happé F. An advanced test of theory of mind: understanding of story characters' thoughts and feelings by able autistic, mentally handicapped, and normal children and adults. J Autism Dev Disord 1994; 24: 129-54.
43 Abell F, Happé F, Frith U. Do triangles play tricks? Attribution of mental states to animated shapes in normal and abnormal development. Cog Dev 2000; 15: 1-16.

44 Jones CR, Swettenham J, Charman T, Marsden AJ, Tregay J, Baird G, et al. No evidence for a fundamental visual motion processing deficit in adolescents with autism spectrum disorders. Autism Res 2011; 4: 347-57.

45 Baron Cohen S. Out of sight or out of mind? Another look at deception in autism. J Child Psychol Psychiatry 1992; 33: 1141-55.

46 Baron Cohen S. The autistic child's theory of mind: a case of specific developmental delay. J Child Psychol Psychiatry 1989; 30: 285-97.

47 Bowler DM. "Theory of Mind" in Asperger's syndrome. J Child Psychol Psychiatry 1992; 33: 877-93.

48 Tregay J, Gilmour J, Charman T. Childhood rituals and executive functions. Br J Dev Psychol 2009; 27: 283-96.

49 Reitan RM, Wolfson D. The Halstead-Reitan Neuropsychological Test Battery: Theory and Clinical Interpretation. Neuropsychology Press, 1985.

50 Simonoff E, Jones CR, Pickles A, Happé F, Baird G, Charman T. Severe mood problems in adolescents with autism spectrum disorder. J Child Psychol Psychiatry 2012; 53: 1157-66.

51 Moffitt TE, Silva PA. IQ and delinquency: a direct test of the differential detection hypothesis. J Abnorm Psychol 1988; 97: 330.

52 Fontaine NM, McCrory EJ, Boivin M, Moffitt TE, Viding E. Predictors and outcomes of joint trajectories of callous-unemotional traits and conduct problems in childhood. J Abnorm Psychol 2011; 120: 730.

53 Collishaw S, Maughan B, Goodman R, Pickles A. Time trends in adolescent mental health. J Child Psychol Psychiatry 2004; 45: 1350-62.

54 Bird G, Cook R. Mixed emotions: The contribution of alexithymia to the emotional symptoms of autism. Transl Psychiatry 2013; 3: e285.

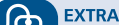

F CONRA

\title{
Psychiatric expertise
}

\section{George Ikkos}

Unlike neurologists, affect not the brain is the object of psychiatrists' specialist medical expertise. Defined as feelings, emotions and agitations, affect integrates human responses and drives brain and body changes, thinking, perceiving, relating and acting. In no particular order, it depends on genes, evolution, culture, physiology, personal experience, social history, chance, meaning, the environment and a sense of self and others. Disturbance in any (combination) of these may lead to psychopathology, the understanding and treatment of which demands biomedical training, empathic curiosity about the human soul, a pluralist perspective, tolerance of anxiety and engagement with public perceptions, policies and ideologies. 